\title{
Economic Factors variables of Purchasing Behaviour of Consumers With Reference to Health Drinks
}

\author{
D. Venkatrama Raju, J. Kannan, C. Archanapriya
}

\begin{abstract}
Wellbeing beverages are typically sodas uncommonly intended to give vitality, nourishment and wellbeing to the human body. They incorporate a blend of methylxanthines, caffeine, nutrient $B$ complex, and home grown fixings. Different fixings may incorporate separates from the guarana plant or taurine, different types of ginseng, maltodextrin, inositol, carnitine, creatine, glucuronolactone, and ginkgo biloba. Some of them contain sugar. The focal fixing in most wellbeing beverages is coca, a similar stimulant found in chocolates, frequently as guarana or yerba mate. These beverages are normally showcased to youngsters.

Larger part of the bustling individuals today are drinking caffeinated drink. This is on the grounds that they accepted that it could truly enhance them vitality and quality. Also, obviously, it could keep them conscious which is perfect for longer long stretches of working. Lion's share of the bustling individuals today are drinking caffeinated drink. This is on the grounds that they accepted that it could truly enhance them vitality and quality. What's more, obviously, it could keep them conscious which is perfect for longer long periods of working.
\end{abstract}

Keywords: Wellbeing Beverages, Caffeinated Drink

\section{INTRODUCTION}

Wellbeing beverages give the basic supplements to the body for the rapid development and recuperation on account of any damage or disease. It for the most part supplements the inadequacy in the admission of the fundamental supplements for the body missing or present in a lot of lower amounts in our ordinary eating routine. The market of the wellbeing beverages is worldwide and covers all aspects of the world[1]-[3]. They are prevalent in same level whether it is a created nation or an immature one. In the Asian nations wellbeing beverages are commonly required by the youthful and old the same. The greater part of the lady people likewise devour them in enormous amount.

Numerous individuals drink nutrient water and accept they are expending a wellbeing drink, yet cotton sweet is great, fat free nourishment. One nourishment reality to note on the name of the nutrient water is that each jug contains 2.5 servings. As indicated by the mark, each serving contains $10 \%$ of your day by day necessities for Vitamins A, B3, B6,

Revised Manuscript Received on December 11, 2019.

D. Venkatrama Raju, Department of Commerce and Economics, Bharath Institute of Higher Education and Research, Chennai , India. Email: prof.dvraju@gmail.com

J. Kannan, Department of Commerce and Economics, Bharath Institute of Higher Education and Research, Chennai , India. Email: sjkannan1986@gmail.com

C. Archanapriya, Department of Commerce and Economics, Bharath Institute of Higher Education and Research, Chennai , India. Email: Archanapriya854@gmail.com

B12, and B5 and a weighty $40 \%$ of your every day stipend of Vitamin C. There are some great all characteristic wellbeing drink equations that contain live proteins, genuine entire nourishment nutrients, and a larger number of supplements than you would ever get from an instance of nutrient water, however you won't locate those predominant wellbeing drink items at the comfort store.

Lift caffeinated drink is perfect for people who needed to keep wakeful and dynamic during the rushed hours. Be that as it may, it ought to be overcome with legitimate mindfulness and care. In the event that you need to ensure about the caffeinated drink that you need to drink, counsel your primary care physician[4]-[7]. It is constantly pleasant to request a specialist's supposition so as to keep away from conceivable peril and dangers in your wellbeing.

\section{OBJECTIVES}

1. To study the role of health drinks in human life.

2. To study consumer delight with refer to health.

3. To measure the attitude of the consumer towards health drinks.

4. To measure the satisfaction of consumers towards health drinks.

5. To evaluate the role of price, quality, quantity, etc in consumer decision making and satisfaction with regard to health drinks

\section{A. Scope of the Study}

1. The scope of the study is to cover all health drink buyers behavior.

2. The main scope is to find satisfaction of the consumers towards the health drinks

\section{B. Need for the Study}

1. To know the satisfaction of the consumer

2. To know the factors which affect the consumer to buy the product.

\section{RESEARCH METHODOLOGY}

The study on consumer behavior of health drinks is based on primary and secondary basis

\section{A. Primary data}

Primary data have been collected from the users of health drinks with the help of questionnaires. A well structured questionnaire was prepared and distributed to the consumers of health drinks. Complete questionnaires from 100 respondents were received. 


\section{Economic Factors variables of Purchasing Behaviour of Consumers With Reference to Health Drinks}

Since there is no published secondary data regarding the factors influencing consumer behavior, primary data was collected with the help of structured questionnaire[8]-[10].

\section{B. Secondary data}

Secondary data were collected from websites. Details were also collected from consumer's experience.

\section{Sample Size}

The sample size taken for the study is 100 . Simple random technique is used for analyzing the data.

\section{Analysis of Data}

The data collected were classified and related methodically. Analysis and interpretation of data was made by using chi-square. The tables were analyzed and inferences were drawn to study the consumer behavior.

\section{RESULTS AND DISCUSSIONS}

a. It is found that most of the female take health drinks more when compare to male, according to analysis.

b. Very few of the male respondents do not have the habit of taking health drinks. It is found that few male and female take health drinks rarely[11]-[14].

c. It is found that most of the male and female respondents came to know about the health drinks through company advertisement first and secondly through friends and relatives.

d. $56 \%$ of the male prefer Boost, whereas $33 \%$ of the female prefer horlicks as their favorite health drinks.

e. The main reason for preferring their favorite health drinks are taste and flavor.

f. It is found that the decision of buying the product is made by wife.

g. It is found that based on quality, quantity, brand, the health drinks is purchased.

h. Most of the male and female respondents change their brand, because of low quality and high price.

i. It is found that most of the male and female respondents are satisfied with the health drinks and they even suggest their health drinks to others.

j. It is found that price, quality, quantity, and availability are the motivating factor in buying the product[15]-[19].

$\mathrm{k}$. It is found from different kind of brand that, health drinks preferred by the user community is boost only.

\section{V.SUGGESTIONS}

The following suggestions are recommended

- From the research conducted, if the quality of boost is improved, it would have still had a better market.

- As the customer is ready to consume the same brand, in respect of prices, the prices can be flexible.

- To improve the sales of the company, it can improve the packaging.

- Changes in packing, designing of the product will increase the sale.

\section{CONCLUSION}

Modern marketing is complex in nature and consumer oriented. Unless or otherwise the consumers are kept delighted; the product is thrown out from the market. If the consumers are not delighted, they reject the products, because consumers expect their product give benefits and keep their expectation fulfilled. Modern consumers are highly rational in selection of a particular product, unlike the traditional buyers to modern buyers buy their product by analyzing all the factors in to account. Before purchasing the product all information's are analyzed in different angle. If the product gives more satisfaction to the consumer, he keeps going for repeated purchase otherwise he will switch over to some other alternate product[20]-[13].

While drawing any definite conclusion from this exploratory research, certain limitations of methodology must be born in mind. The study was conducted in just one city. Further only a small sample of 100 respondents taken as representative of all products in the market place was used for the study. Despite of those limitations, important conclusions that emerge from this research are of considerable value of marketing management in its decision making.

The data indicate is quite conclusively a significant amount of brand loyalty does exist within a given category. From the study it is clearly established that behaviorally and attitudinally loyal drinks are larger in number and continued from the study, it is clearly understood that a consumer develops a strong attachment to a specific brand in a given product category and in addition to it, the purchase is repeated. This is called brand loyalty.

Consumer appraisal of the distinctiveness of a brand is physical attributes not only affect the brand image but also has important implications of marketing. When consumers believe the brand it image tends to be associated with the personalities of the people who are through to buy it.

A consumer while sticking to a particular brand must be attitudinal loyal. Here mental and physical attributes are coming to act. In this study it is clearly established that physical features are important for the selection of any brand of the health drinks[24]-[25].

Therefore consumer satisfaction is the secret behind the success of any product. Those who fail to satisfy the consumer, faces the product failure. Because 'consumer is the king in market.

\section{REFERENCES}

1. Vasanthi, S. \& Rabiyathul Basariya, S. 2019, "Influence of value analysis and cross training in industry", International Journal of Engineering and Advanced Technology, vol. 8, no. 6, pp. 1810-1811.

2. Velvizhi, R., Sri Gowtham, S. \& Jeya Priya, D. 2019, "Examination of early feedbacks for effective product retailing on E-commerce websites", International Journal of Engineering and Advanced Technology, vol. 8, no. 6 Special Issue 2, pp. 703-706.

3. Anuradha, C., Pothumani, S. \& Kavitha, R. 2019, "A novel method towards E-commerce", International Journal of Engineering and Advanced Technology, vol. 8, no. 6 Special Issue 2, pp. 535-538.

4. Thomas, J. \& Rabiyathul Basariya, S. 2019, "A study on the issues of financial ratio analysis", Indian Journal of Public Health Research and Development, vol. 10, no. 3, pp. 1079-1081.

5. [5] Ramachandran, S. \& Rabiyathul Basariya, S. 2019, "Online marketing - study on customer satisfaction and relationship", Indian Journal of Public Health Research and Development, vol. 10 , no. 3 , pp. $1072-1078$. 
6. Priya, R., Vinothini, G. \& Cor Jesu, C.D. 2019, "The mentor-protégé relationship for professional growth", Journal of Advanced Research in Dynamical and Control Systems, vol. 11, no. 9 Special Issue, pp. 1110-1119.

7. Jannifer Rani, N., Bina Pani, S. \& Nimisha, N.S. 2019, "A study on money back polices available in LIC", Journal of Advanced Research in Dynamical and Control Systems, vol. 11, no. 9 Special Issue, pp. 833-839.

8. Saillaja, V., Jhansi Rani, K. \& Catherine, R. 2019, "Global marketing management planning and organization", Journal of Advanced Research in Dynamical and Control Systems, vol. 11, no. 9 Special Issue, pp. 489-493.

9. Saillaja, V., Jhansi Rani, K. \& Catherine, R. 2019, "The new phase of marketing information system", Journal of Advanced Research in Dynamical and Control Systems, vol. 11, no. 9 Special Issue, pp. 482-488.

10. Thoufiqulla \& Raju, D.V. 2019, "Perception of indian investor towards investment in mutual funds with special reference to mip funds", Journal of Advanced Research in Dynamical and Control Systems, vol. 11, no. 5, pp. 177-183.

11. Jasmine, K.R.M. \& Basariya, S.R. 2018, "A study on the customers benefits on mutual funds", International Journal of Civil Engineering and Technology, vol. 9, no. 4, pp. 45-48

12. Vasanthi, S. \& Basariya, S.R. 2019, "Pros and cons of on the job training versus off the job training", International Journal of Scientific and Technology Research, vol. 8, no. 10, pp. 671-674.

13. Pavithra, J. \& Ganesan, M. 2016, "A study on awareness and impact of micro-financial schemes", International Journal of Applied Business and Economic Research, vol. 14, no. 8, pp. 5449-5460.

14. Pavithra, J., Dilli Babu, P. \& Ambuli, T.V. 2014, "A study on budgetary control at Maruti Service Masters, Chennai", International Journal of Applied Business and Economic Research, vol. 12, no. 2, pp. 151-161.

15. Gunaraja, T.M. \& Venkatrama Raju, D. 2018, "Determining factors of organisational climate with reference to leadership styles", International Journal of Mechanical Engineering and Technology, vol. 9, no. 9, pp. 1327-1332.

16. Gunaraja, T.M. \& Venkatrama Raju, D. 2018, "The role of job satisfaction and training of employees in determining organisational climate of a selected industry", International Journal of Civil Engineering and Technology, vol. 9, no. 8, pp. 1266-1269.

17. Aarathy, T.S. \& Raju, D.V. 2018, "Performance appraisal and its effects on employees with respect to it sector in Chennai city", International Journal of Civil Engineering and Technology, vol. 9, no. 6, pp. 1535-1538.

18. Aarathy, T.S. \& Raju, D.V. 2018, "Employee perception towards performance appraisal system in IT sector", International Journal of Mechanical Engineering and Technology, vol. 9, no. 5, pp. 131-135.

19. Porselvi, W., Jublee, D. \& Sivanesan, G. 2018, "A study on factor influencing adoption of technology and innovation in banking industry, tamilnadu, India", International Journal of Mechanical Engineering and Technology, vol. 9, no. 5, pp. 789-800.

20. Akessa, G.M. and Dhufera, A.G., 2015. Factors That Influences Students Academic Performance: A Case of Rift Valley University, Jimma, Ethiopia. Journal of Education and Practice, 6(22), pp.55-63.

21. Miller, G. and Shih, C.C., 1999. A faculty assessment of the academic rigor of on-and off-campus courses in agriculture. Journal of Agricultural Education, 40, pp.57-65.

22. Tsinidou, M., Gerogiannis, V. and Fitsilis, P., 2010. Evaluation of the factors that determine quality in higher education: an empirical study. Quality Assurance in education, 18(3), pp.227-244.

23. Farooq, M.S., Chaudhry, A.H., Shafiq, M. and Berhanu, G., 2011. Factors affecting students' quality of academic performance: a case of secondary school level. Journal of quality and technology management, 7(2), pp.1-14

24. Fitsilis, P., Gerogiannis, V. and Anthopoulos, L., 2014. Ontologies for software project management: a review. Journal of Software Engineering and Applications, 7(13), p.1096.

25. Adams, J.D. and Jaffe, A.B., 1996. Bounding the effects of R\&D: an investigation using matched establishment-firm data(No. w5544). National bureau of economic research.

\section{AUTHORS PROFILE}

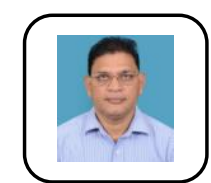

D. Venkatrama Raju, Professor, Department of Commerce and Economics, Bharath Institute of Higher Education and Research, Chennai, India.

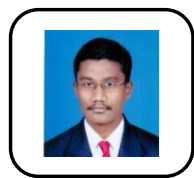

J. Kannan, Associate Professor, Department of Commerce and Economics, Bharath Institute of Higher Education and Research, Chennai , India.

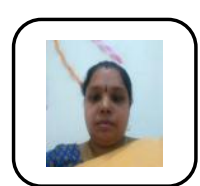

C. Archanapriya, Assistant Professor, Department of Commerce and Economics, Bharath Institute of Higher Education and Research, Chennai, India. 